CHAPTER 1

\title{
The Netherlands as a Laboratory of Knowing: Introduction to Locations of Knowledge in Dutch Contexts
}

\author{
Fokko Jan Dijksterhuis and Andreas Weber
}

No, Netherland does not bow! in the kingdom of science, she maintains her glory, stands on the highest stage. HELMERS, $1812^{1}$

Between 1824 and 1844 the Dutch baron and parliamentarian Hendrik Collot d'Escury van Heinenoord (1773-1845) wrote a multi-volume book on the sciences and arts in the Netherlands: Holland's Roem in Kunsten en Wetenschappen ('The Glory of Holland in the Arts and Sciences'). ${ }^{2}$ He used the above lines as epitaph, from an ode on the Dutch nation. Collot erected a literary monument for a new state, the Kingdom of the Netherlands, that had just been established in 1815, after the defeat of Napoleon. It was the successor of the Dutch Republic, the idiosyncratic federation of provinces in the Low Countries that existed from 1588 to 1795 . With the book Collot situated the new state in the global theatre of nation states as a prominent contributor to scientific and artistic progress.

The essays in this volume address knowledge practices in the Netherlands. They are not, however, exclusively about 'Dutch' knowledge production. They are particularly about locations: space- and time-specific configurations of actors, artefacts, and activities. The Dutch setting is what binds together the various locations discussed in this volume. The authors discuss the ways in

1 J.F. Helmers, De Hollandsche Natie, in zes zangen (Den Haag: J. Allart, 1812), ve zang. "Neen Neerland zwicht niet! in het rijk der wetenschap,/Handhaaft zij haren roem, staat op den hoogsten trap."

2 H. Collot d'Escury, Holland's Roem in Kunsten en Wetenschappen, 7 volumes (Den Haag: Van Cleef, 1825-1844). 
which knowledge practices were shaped by the places of knowledge production. The cases are situated in the Netherlands, at different kinds of locations and at different moments between 1600 and 1980 . We use 'the Netherlands' as shorthand for a historically fluid category referring to a more or less coherent geographical area in the Low Countries that had porous borders and an evolving sociocultural make-up. The Netherlands encompasses a range of locations with specific features. In some cases these features are fairly idiosyncratic such as the decentral place of noble courts in the early modern Republic - in other respects the locations are comparable to other places around the globe. ${ }^{3}$ Together the chapters present a variety of locations that enables comparisons and provides further insight into the way locations shaped knowledge practices. They were part of the broader history of the Dutch Republic and the Kingdom of the Netherlands that shaped the Netherlands and its relationships with the world. Some readers may be disappointed that we do not follow in the trails of Collot and praising the glory of the Dutch.

The common designation 'the Netherlands' refers to a state with changing make-up whose borders were changeable and often permeable (see figure 1.1). ${ }^{4}$ 'The Netherlands' also indicates a fluid spatiality and identity as a geographical node and sociocultural space. At the same time 'the Netherlands' is defined as much by its internal make-up as by its relationships with the outside world: from the early modern networks of urban 'nations' and world trade to the global fabric of modern colonies and post-colonies.

In the Low Countries, a new and rather idiosyncratic state emerged from the sixteenth century which included the northern provinces, the Republic of Seven United Netherlands (or Provinces; $1588-1795$ ). The Republic was a multilayered society where power and wealth were distributed at all levels: between

3 Cf. Paul A. Elliott, Enlightenment, Modernity and Science: Geographies of Scientific Culture and Improvement in Georgian England (London / New York: I.B. Tauris, 2010).

4 James C. Kennedy, A Concise History of the Netherlands (Cambridge: Cambridge University Press, 2017); A Miracle Mirrored. The Dutch Republic in European Perspective, eds. Karel Davids and Jan Lucassen (Cambridge: Cambridge University Press, 1995); Nederlandse cultuur in Europese context 1650-20oo. Rekenschap, eds. D. Fokkema and F. Grijzenhout (Den Haag: Sdu, 2001); A History of Science in the Netherlands, eds. K. van Berkel, A. van Helden and L. Palm (Leiden: Brill, 1999); Technology and the Making of the Netherlands. The Age of Contested Modernization, 1890-1970, eds. Johan Schot, Harry Lintsen and Arie Rip (Boston, MA: MIT Press, 2010). 


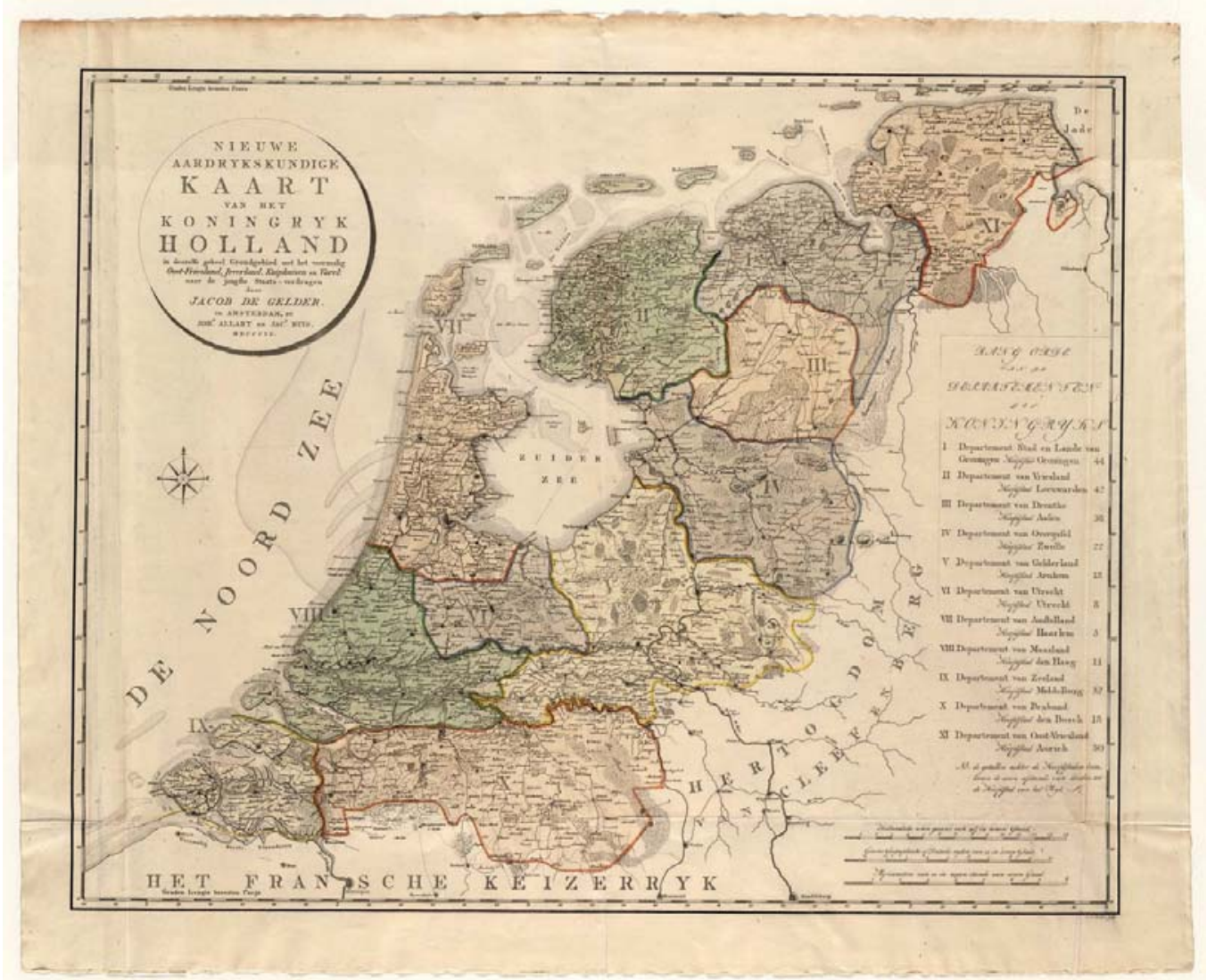

FIGURE 1.1 "Nieuwe Aardrykskundige Kaart van het Koningryk Holland” by Jacob de Gelder, 1810

This map of the Low Countries is rather unfamiliar to Dutch eyes. Not only are the provincial borders unrecognizable, the whole contours of the state are different. Still, this is quite characteristic of the Netherlands. Large parts of the south and east regions were not demarcated definitively and spheres of influence and afffinity stretched beyond political borders. Moreover, overseas networks and terrorities defined 'the Netherlands' throughout the early modern and modern periods. The map is from the period of French domination (1795-1813) when large parts of the structure of the modern Kingdom of the Netherlands were created including the royal foundation. In that sense it is also typical of the Netherlands, being a state that has coevolved with European and global histories.

the towns and regions making up the provinces; between the patrician families and institutions in the urban centres. In principle, every Dutch province was its own sovereign. And in every province the power was distributed over the various cities and its magistrates, as well as over the landed classes. However, the provinces were bound together by a union, ruled by the States-General with representatives from all seven provinces, who arranged foremost matters of foreign policy and national defence. On the levels of both the state and the province, Stadtholders (noblemen from the Dillenburg Nassau family) were 
chosen to represent military interests, but with only limited governing powers. The whole concept of centrality was alien to the Dutch Republic, at least until the late eighteenth century when unifying tendencies anticipated the patriotic aspirations for a nation state.

The Kingdom of Holland, erected in 1806 upon the groundwork of the patriotic and French reorganization of the state, was a centralised Napoleonic state, where the foundations were laid for the Kingdom of the Netherlands, a constitutional monarchy with central government and national orientation, that came into being in 1815 . Paradoxically, this turn to a modern nation went hand in hand with a shift in power from the urban trade centres to the rural structures of agricultural and industrial regions. ${ }^{5}$ More importantly, the nineteenthcentury nation was built upon overseas territories that transformed the Dutch global trade network into a colonial empire. ${ }^{6}$ Where the Dutch Republic existed as a transit zone of both European and global commercial networks of trade, the Kingdom of the Netherlands capitalized on the exploitation of overseas territories - especially in the Malay Archipelago and the Caribbean. If there is any continuity in 'the Netherlands,' it is the position at the coast as an entrepôt in commercial and cultural connections all over the world. Up until today Dutch economy and politics are dominated by the interests of global trade and entrepreneurship. ${ }^{7}$

Collot's ode to Dutch glory fitted the new conceptions of what knowledge was and what constituted a state. Enlightenment thinkers increasingly interpreted knowledge as a universal entity that progressed over time. With this conception they had begun writing a history of knowledge as a narrative of growth and improvement and the gradual uncovering of truth and proper method. ${ }^{8}$ Besides disciplinary divisions and an increasing separation of formal and tacit knowledge practices, The Enlightenment combined the idea of universal knowledge with the emergent concept of the nation state. Specific nations would contribute to scientific progress and such contributions would reflect the glory and character of the nation. This paradoxical amalgam of

5 P. Brusse and W.W. Mijnhardt, Towards a new template for Dutch history. De-urbanisation and the balance between city and countryside (Zwolle: Waanders, 2011).

6 Catia Antunes and Jos Gommans, Exploring the Dutch Empire. Agents, Networks and Institutions, 1600-200o (London: Bloomsbury, 2015).

7 See also Harold Cook, "Amsterdam, entrepôt des savoirs au XVII ${ }^{\mathrm{e}}$ siècle," Revue d'histoire moderne \& contemporaine 55-2 (2008): 19-42.

8 As pioneered and exemplified by Jean-Étienne Montucla, Histoire des Mathematiques (Paris: Jombert, 1758; extended edition 1799-1801); Joseph Priestley, The History and Present State of Discoveries Relating to Vision, Light and Colours (London: Johnson, 1772) (preceded by The History and Present State of Electricity of 1768). 
universality and individuality opened a competition between nations over inventions, discoveries and priorities. The rivalry over universal knowledge was part of the contest over global power and wealth. Politically, economically, and culturally, the nation state was defined by its overseas territories and its cultural reputation anchored in realms of universality. ${ }^{9}$

Collot propelled the Netherlands into the race by highlighting the unique character of the Dutch and the incomparable achievements of the Golden Age in particular. This volume turns his story inside out. It is not about the Dutchness of knowledge, let alone the glory of Dutch knowledge production. The Netherlands provides a geographical focus that enables comparison and cross-reference of different types of locations. In this way the Netherlands from the early modern Republic to the modern Kingdom - is a laboratory to investigate the various properties and effects of locations on knowledge production. A laboratory not necessarily in the cliché sense of white coats isolating and testing phenomena, but rather as a multifarious site where phenomena are created and brought under control - or not, when an experiment fails.

In this respect, the volume takes a cue from an article written by Klaas van Berkel on the international relevance of Dutch history. ${ }^{10}$ Van Berkel's 'The Dutch Republic. Laboratory of the Scientific Revolution' may be seen as a reflection upon his earlier history of science in the Netherlands. Originally published in Dutch in 1985, it was included in the 1999 handbook A History of Science in the Netherlands. ${ }^{11}$ In his 2010 article, Van Berkel asked how a Dutch history relates to a history of science in general. He argues that the case of the Netherlands can be used as a historical laboratory to investigate the nature and causes of early modern transformations of science and society.

9 Jürgen Osterhammel, Die Verwandlung der Welt. Eine Geschichte des 19. Jahrhunderts (München: Beck, 2009); R. Drayton, Nature's Government: Science, Imperial Britain, and the "Improvement" of the World (New Haven, CT: Yale University Press, 200o); Michael Werner and Bénédicte Zimmermann, "Vergleich, Transfer, Verflechtung. Der Ansatz der Histoire croisée und die Herausforderung des Transnationalen," Geschichte und Gesellschaft 28-4 (2002) 607-636.

10 Klaas van Berkel, "The Dutch Republic. Laboratory of the Scientific Revolution," BMGN Low Countries Historical Review 125-2,3 (2010): 81-105; Klaas van Berkel and Leonie de Goei, "The International Relevance of Dutch History: Introduction," BMGN - Low Countries Historical Review 125-2,3 (2010): 3-6.

11 Klaas van Berkel, In het voetspoor van Stevin. Geschiedenis van de natuurwetenschap in Nederland 1580-1940 (Meppel: Boom, 1985). It was translated into English and enlarged with some essays as A History of Science in the Netherlands, eds. K. van Berkel, A. van Helden and L. Palm (Leiden and Boston: Brill, 1999). This book can be still considered the most up-to-date general history of science in the Netherlands. 
Our volume takes up the idea of a laboratory, but proposes to broaden both the content and its application. Understanding locations as places of knowledge transformation extends the concept of lab beyond the confines of a secluded research and development laboratory. Van Berkel maintains a rather positivistic conception of a laboratory as a demarcated and institutionalized setting where phenomena are isolated and brought under control (see figure 1.2a). In our view it is problematic to transpose this concept to earlier periods. Moreover, such a narrow conception precludes analytical opportunities to study knowledge practices. By broadening the concept to places like the field, the workshop, the construction site, and even the city, the laboratory becomes a place where historical cases can be studied about the question of how locally situated socio-cultural configurations produce specific knowledge practices. ${ }^{12}$ Locations are laboratories where new configurations of actors and ideals transform processes of knowing.

Van Berkel's reflections focus upon the relationship between the Netherlands and the Scientific Revolution in the seventeenth century. This can be extended towards the eighteenth-century and beyond to include developments as the Enlightenment, industrialization, colonization and globalization. However, such a move also raises the historiographical question of how to approach the relationship between local history and such 'universal' events. Van Berkel argues that the small and demarcated context of the Dutch Republic can help to identify dynamics and crucial variables of general developments. He identifies three elements of society in the Dutch Republic that in his view were conducive for the rise of modern science: (1) an open and sustained interaction between scholars and craftsmen; (2) a prominent role for academic institutions as centres of both teaching and research; and (3) a congruence of scientific and mercantile values. ${ }^{13}$ The Republic reflected general trends like the artisanal involvement, but also had more singular features, for example in higher education. Newly established universities in the Republic were not burdened by the scholastic heritage of old established universities elsewhere in Europe.

12 D. Turnbull, Masons, Tricksters and Cartographers: Comparative Studies in the Sociology of Scientific and Indigenous Knowledge (London and New York: Psychology Press, 200o); Pamela O. Long, Artisan/practitioners and the Rise of the New Sciences, 1400-1600 (Corvallis, OR: Oregon State University Press, 2011); D.N. Livingstone, Putting Science in Its Place. Geographies of Scientific Knowledge (Chicago: University of Chicago Press, 2003). In a review article of $B M G N$ Benjamin Schmidt argues that such efforts to identify specific Dutch features is rather common in Dutch historiography. Benjamin Schmidt, "Dikes and Dunes: On Dutch History and Dutchness," BMGN - Low Countries Historical Review 133-1 (2018): 82-99. 

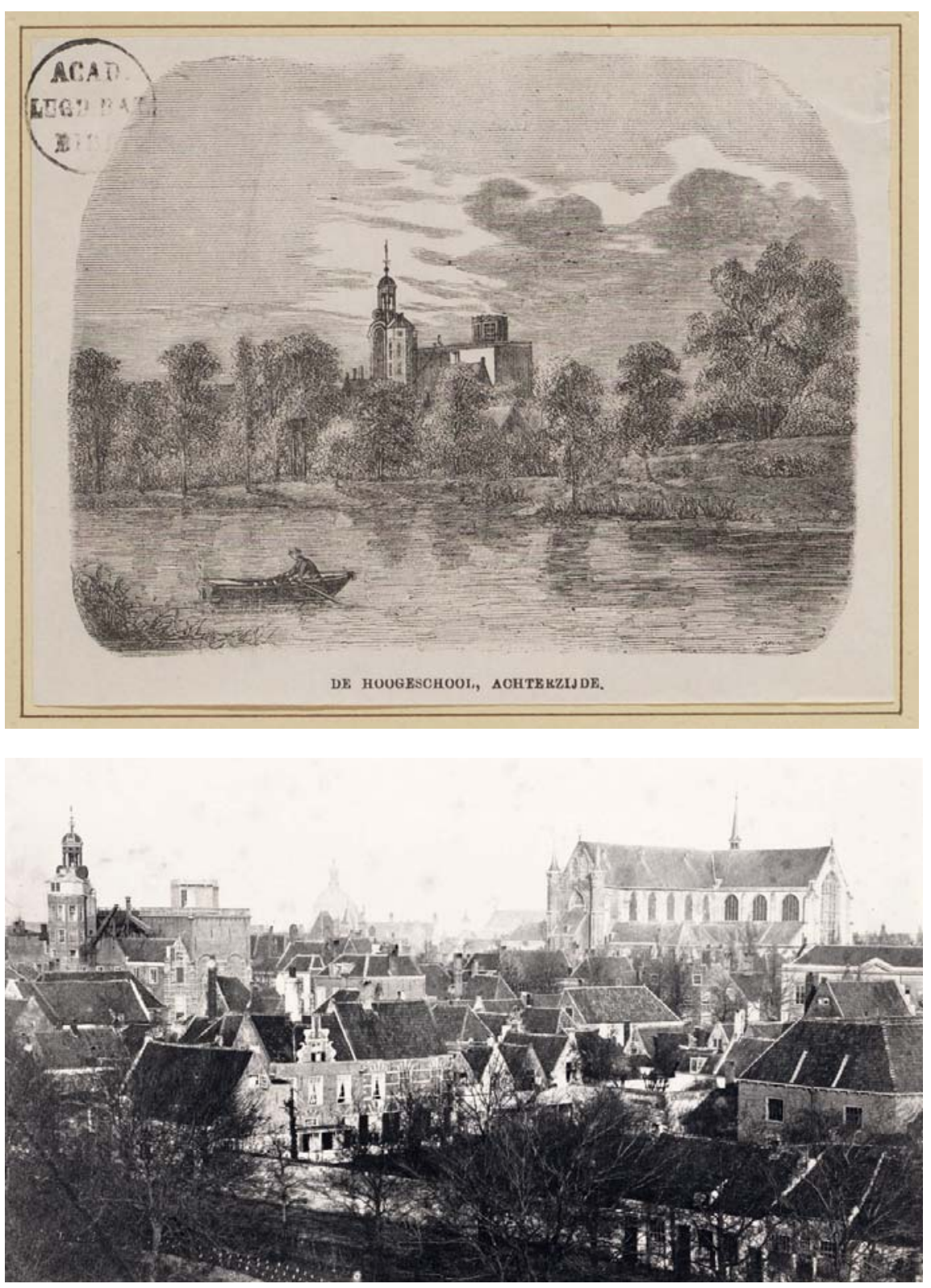

FIGURES 1.2A-1.2B Two nineteenth-century depictions of the Leiden Observatory. The contrasting images nicely illustrate different views of 'the location of science.' The engraving of the 'Hoogeschool' emphasizes the seclusion of research and the autonomy of science. The pictoresque environments of the bastion park offer a tranquil place for observation and contemplation. This is one of the aspects of locations illustrated by the essays in this volume: knowledge is cultivated in specific places where expertise and interests meet. Another aspect is emphasized in the photograph of the town and its academic buildings: knowledge is embedded in wider social and cultural settings. The photograph from 1861 not only shows the messy appearance of a city but also signal the dispersed and often ad hoc character of scientific practice.

SOURCE: LEIDEN UNIVERSITY LIBRARY AND ERFGOED LEIDEN 
However, such an approach considers the Scientific Revolution to be some universal development that affected local circumstances and took specific shape in regional contexts. Such an approach often leads to histories of pioneers and followers, centres and peripheries, boiling down to questions of how the Dutch Republic contributed to 'the' Scientific Revolution. Historiography of the Industrial Revolution instead emphasizes the multiplicity of processes of industrialisation from early modern period onwards. Rather than one Industrial Revolution of coal, textile and private entrepreneurship, originating in the English Midlands, different pathways can be recognized, such as the typical interactions between state, gentry and learned elites in the German lands. ${ }^{14}$ For the Netherlands, Karel Davids has put the early modern rise and decline of technological leadership in comparative perspective. ${ }^{15}$ Taken together, such scholarship shows that explicanda like the 'Scientific Revolution,' 'Enlightenment,' 'Industrial Revolution' tend to evaporate when put in the Petri dish of local history. ${ }^{16}$ Instead of investigating universal history on a local scale, a reverse approach considers a location as a setting that gives shape to situated values and practices (including perceptions of the natural world).

\section{'Location' - Place and Knowing}

The previous section has made clear that what defines a location is far less interesting than what it does. A location is not just a place where things happen to happen. It is a stage that gives shape and meaning to a performance, a performance of knowing in our case. A location creates the setting for knowledge production by bringing people and practices, objects and interests together, and by structuring their interactions. Space is a necessary condition for science; where else could it take place, the historian and sociologist of science

14 Ursula Klein, Nützliches Wissen. Die Erfindung der Technikwissenschaften (Göttingen: Wallstein Verlag, 2016); Landschaften agrarisch-ökonomischen Wissens. Strategien innovativer Ressourcennutzung in Zeitschriften und Sozietäten des 18. Jahrhunderts, ed. Marcus Popplow [Cottbuser Studien zur Geschichte von Technik, Arbeit und Umwelt, vol. 30] (Münster: Waxmann Verlag, 2010). Thomas Misa shows how heterogeneous industrialization in different places in England was: Thomas Misa, Leonardo to the Internet. Technology and Culture from the Renaissance to the Present (Baltimore: Johns Hopkins University Press, 2004).

15 Karel Davids, The Rise and Decline of Dutch Technological Leadership. Technology, Economy and Culture in the Netherlands, 1350-180o (Leiden: Brill, 2008).

16 See above: Withers, "Place and the Spatial Turn"; Negotiating Knowledge in Early Modern Empires. A Decentered View, eds. L. Kontler, A. Romano, S. Sebastiani and B.Z. Török (New York: Palgrave, 2014); Annapurna Mamidipudi, Towards a theory of innovation in handloom weaving in India (Maastricht: Maastricht University, 2016). 
Steven Shapin once rhetorically asked. ${ }^{17}$ Knowing situated in time and place and the outcomes of inquiry cannot be abstracted from where they are produced. As Ludwik Fleck detailed in his monumental 1935 study, 'Erkennen' ('Understanding') is a social and cultural phenomenon rooted in the interactions and evolutions of concrete communities. ${ }^{18}$ Fleck's emphasis on the local and material circumstances of research has been taken up again in the last quarter century. In this introduction we draw upon some concepts that have been developed to detail and problematize the situatedness of knowledge production. ${ }^{19}$

Besides providing spatial configurations for ways of knowing and making, locations also mediate relationships. They connect different actors, confronting and aligning interests and ambitions, and they trigger the development of specific knowledge practices. The idea of location as a junction of social, cultural, political, and economic relationships employs the concept of trading zone as developed by Peter Galison and Pamela Long. ${ }^{20}$ Discussing twentiethcentury particle physics, Galison showed how seemingly incommensurable world readings can become connected when people act together, irrespective of the different interpretations of the materials shared and exchanged. Pamela Long has transposed this idea to the early modern period in an effort to understand interactions between scholars and artisans. The early modern period witnessed a transition of knowledge cultures in which roles of actors were in flux and not institutionally fixed. In Long's discussion of a number of trading zones, the rearrangement of such roles is illustrated and analysed. ${ }^{21}$ The

17 Steven Shapin, "Review of David Livingstone: Science, Space and Hermeneutics," British Journal for the History of Science 36 (2003): 89-90.

18 Ludwig Fleck, Entstehung und Entwicklung einer wissenschaftlichen Tatsache. Einführung in die Lehre vom Denkstil und Denkkollektiv (Frankfurt am Main: Suhrkamp, 1980) 56-6o.

19 Hans-Jörg Rheinberger, Toward a History of Epistemic Things. Synthesizing Proteins in the Test Tube (Redwood City: Stanford, 1997) ('Experimentalsystem'); see next footnote for 'trading zones'; see also Sites of Mediation. Connected Histories of Places, Processes, and Objects in Europe and Beyond, 1450-1650, eds. Susanna Burgharz, Lucas Burkart and Christine Göttler (Leiden and Boston: Brill, 2016); Kocku von Stuckrad, Locations of Knowledge in Medieval and Early Modern Europe: Esoteric Discourse and Western Identities (Leiden and Boston: Brill, 2010); Science as Cultural Practice: Vol. I: Cultures and Politics of Research from the Early Modern Period to the Age of Extremes, eds. Moritz Epple and Claus Zittel (Berlin: De Gruyter, 2014).

$20 \quad$ Peter Galison, Image \& Logic. A material culture of microphysics (Chicago: The University of Chicago Press, 1997); Pamela O. Long, "Trading Zones in Early Modern Europe," Isis 106-4 (2015): 840-847.

21 Long, Artisan/practitioners responds to Edgar Zilsel's 1942 argument that the influence of artisanal knowledge practices on scholars was crucial to the Scientific Revolution. She emphasizes the interaction and mutual transformation of knowledge practices into new ones, precipitating into modern institutionalized domains from the eighteenth century. 
concept of trading zone emphasizes the fluidity of roles of actors, as they are shaped by interactions rather than the other way around. The contributions in this volume build upon such notions of localizing knowledge practices and showcase the variety of configurations and their outcomes.

What also binds the cases in this volume together is the evolving scene of the Netherlands over the early modern and modern periods. It thus ties in with attempts by David Livingstone and others to write a history of knowledge from a geographical perspective. ${ }^{22}$ A geography of knowledge perspective emphasizes the ways in which specific knowledge practices emerge from a variety of sites and how circulation between different sites creates translocal qualities of knowledge. On a regional scale this means that different sites interact in cultural contexts that both assign meaning and value to knowledge practices and are shaped by them. Building upon Livingstone, Simon Naylor argues that such contexts are nested at different levels: city, region, nation, as well as global networks of power, commerce and knowledge. ${ }^{23}$ The Netherlands presents various instances of such multi-layered contexts. For instance, the early networks of cities were intertwined with their global linkages. Or, the rise of modern disciplinary structures in the sciences was entangled with the construction of the Dutch national and colonial system. A long-term view enables us to illustrate and understand that such contexts of identification and valuation were often only temporarily anchored. Naylor identifies a third aspect of the geography of knowledge, which he describes as the way in which science reciprocally creates geographies. This is not central to this volume, although it is touched upon in some of the essays, such as Fokko Jan Dijksterhuis's account of Golden Age Amsterdam and Azadeh Achbari's analysis of imperial networks of meteoreology in the long nineteenth century. In a more general sense, one of the underlying ideas of this volume is that such knowledge practices also contributed to the shaping of 'the Netherlands.'

Long identifies three features of early modern trading zones: driven by 'technological' projects, substantial interest of elites, and involving persons with markedly fluid careers.

Livingstone, Putting Science in Its Place; A. Ophir and S. Shapin, "The place of Knowledge: The Spatial Setting and Its Relation to the Production of Knowledge," Science in Context 4:1 (1991): 3-21; Charles W.J. Withers, "Place and the 'Spatial Turn' in Geography and in History," Journal of the History of Ideas 70-4 (2009): 637-658; Diarmid A. Finnegan, "The Spatial Turn: Geographical Approaches in the History of Science," Journal of the History of Biology 41 (2008): 369-388; Geographies of Nineteenth-Century Science, eds. David N. Livingstone and Charles W.J. Withers (Chicago: University of Chicago Press, 2011).

23 Simon Naylor, "Introduction: historical geographies of science - places, contexts, cartographies," The British Journal for the History of Science 38 (2005): 1-12. For a general reflection see also L.L. Roberts, "Situating Science in Global History: Local Exchanges and Networks of Circulation," Itinerario 33 (2009): 9-30. 


\section{$3 \quad$ Structure of This Volume: Three Aspects of Locations}

We divided the volume in three sections that highlight different aspects of locations: a kind of location, the city; a specific feature of locations, their connections over time and place; and an effect of locations, the transformation of knowing. The essays also interconnect these three aspects, for example the way exchanges over networks transform the matters that are moved. Likewise, global connections have been defining for cities and national institutes alike. Recent historiography has made clear that circulation is a main agent of knowledge transformation. This volume draws upon this perspective, but focuses on the transformative working of locations rather than circulation between locations. ${ }^{24}$

The City is a specific kind of location. It can be considered as a location itself, but it also contains specific urban places. In his sketch of city improvement in Golden Age Amsterdam, Dijksterhuis explores how the city as such gave rise to particular forms of knowledge production. Gerhard Wiesenfeldt shows how the characteristics of Leiden as an industrial town affected the organization and ambitions of the university. In his essay he presents the university as an urban institution and the 'engineering school' as a product of Leiden's industrial character in that time. Huib Zuidervaart uses the case of Middelburg to discuss anatomical theatres as a product of an ambitious urban culture that was the cornerstone of the Dutch Republic. Anatomical theatres created a new kind of node that gave rise to a knowledge practices in which the interests of professionals and urban bureaucratic elites were integrated. Zuidervaart describes a dynamics that is usually associated with learned societies of the eighteenth century. The three cases in this section present a varied picture of the urban cultures and remind us of the central role cities played in the Dutch Republic. Historiography of the city as a place of knowing has been developing only recently, most notably in Deborah Harkness's account of Early Modern London and Sven Dierig's study of nineteenth-century Berlin. ${ }^{25}$ Trendsetting

24 Silent Messengers. The circulation of Material Objects of Knowledge in the Early Modern Low Countries, eds. Sven Dupré and Christoph Luthy (Berlin: LIT Verlag, 2011); Cultural Transfer Through Translation. The Circulation of Enlightened Thought in Europe by Means of Translation, ed. Stefanie Stockhorst (Amsterdam: Rodopi, 2010).

25 D.E. Harkness, The Jewel House. Elizabethan London and the Scientific Revolution (New Haven, CT and London: Yale University Press, 2007); Sven Dierig, Wissenschaft in der Maschinenstadt. Emil Du Bois-Reymond und seine Laboratorien in Berlin (Göttingen: Wallstein, 2006). The topic is addressed in a more general way in Science and the City, eds. Sven Dierig, Jens Lachmund and Andrew Mendelsohn [Osiris 18] (Chicago: Chicago University Press, 2003). See also H. Cook, Matters of Exchange. Commerce, Medicine, and Science in the Dutch Golden Age (New Haven, CT: Yale University Press, 2007). 
in this respect has been the late 1990s project on urban achievements in early modern Europe. ${ }^{26}$ It presented an interdisciplinary, comparative account of Antwerp, Amsterdam, and London, along different themes aimed at understanding the dynamics of flourishing and the relationship with urban settings. In urban history, issues of knowledge production are also addressed, querying how specific features of cities stimulate innovation as well as the nature and agency of the city as such. ${ }^{27}$ Alette Fleischer draws upon these debates by highlighting how 'the' city is defined by mycelial structures of early modern towns, rather than as a locally delimited entity.

The section Networks exemplifies how locations establish connections over time and place and how these connections produce specific ways of knowing. In her study on the Danzig naturalist and collector Jacob Breyne, Fleischer approaches the early modern city as a node of mercantile routes. Her reconstruction of the activities of the Breyne family showcases how personal and commercial ties fostered knowledge transfer. In a similar vein, but then with a focus on the modern period, Achbari argues how European aspirations in global trade and empire laid the foundation for a new scientific discipline of meteorology. By describing the gradual development of international conferences in medicine and natural history, Ilja Nieuwland presents a parallel case, but then with a special focus on the nationalization and professionalization of other scientific disciplines as they emerged in the nineteenth century. Both essays tellingly show how networks that enabled the coordination of a large number of individuals at different places appear as the very location of knowledge production. Abel Streefland extends this line of reasoning to the twentieth century by showing how the efforts of the Netherlands to position itself in international politics shaped Dutch nuclear science.

The final section on Transformations shows how locations process knowledge. Instead of departing from the notion that transformations always lead to new knowledge, this section rather focusses on processes of combining, recombining and reinterpreting already available knowledge through

26 Urban Achievement in Early Modern Europe. Golden Ages in Antwerp, Amsterdam and London, eds. Patrick O'Brien, Derek Keene, Marjolein 't Hart and Herman van der Wee (Cambridge: Cambridge University Press, 2001).

27 Bert De Munck, "Disassembling the City: A Historical and an Epistemological View on the Agency of Cities," Journal of Urban History 43-5 (2016): 811-829; Gert-Jan Hospers, "Creative Cities: Breeding Places in the Knowledge Economy," Knowledge, Technology, \& Policy 16-3 (2003): 143-162; Ali Madanipour, Knowledge Economy and the City: Spaces of Knowledge (Oxon: Routledge, 2013). An urban history perspective on early knowledge societies is developed in Knowledge and the Early Modern City. A History of Entanglements, eds. Bert De Munck and Antonella Romano (Oxon: Routledge, 2019). 
different methods of test, proof and rejection. It presents widely different sorts of locations - stable, lectern, museum, R\&D lab - to be able to distinguish and compare different settings of knowledge production. Dirk van Miert illustrates how the oratory processing of knowledge in the form of disputation produced new textual knowledge. Seen from this perspective, the lectern can be read as a Petri dish and the lecture hall as the laboratory where the research took place. Martin Weiss shows how Teylers Museum in Haarlem gradually transformed from a laboratory where new scientific knowledge was made into a display of what science was considered to be. Floor Haalboom shifts the focus to cowsheds in the countryside in which academic and industrial attitudes were juxtaposed. In doing so, all involved actors brought forward new conceptions of hygiene. Marijn Hollestelle, in turn, contrasts academic and industrial laboratories as different sites of $R \& D$ where polymer chemistry was processed.

The essays in this volume also display links between the sections and thus the different aspects of the way locations mediate knowledge production. Zuidervaart offers an exquisite example of the way the urban setting of Middelburg gave a specific shape to medical and anatomical knowledge, thus showing how the city also transformed a body of knowledge. Conversely, the transformations that Weiss sketches as occurring in the 19th-century Teylers Museum were also embedded in the setting of urban culture. Fleischer shows how the early modern merchant town can be understood from a network perspective. The exemplary laboratories presented by Hollestelle were essentially networked in the fabric of industry and academia. Achbari discusses the rise of a new location, the sea, that both transformed meteorological inquiry and was transformed by the mercantile, imperial, and scientific interests underlying the rise of a new discipline. Nieuwland shows how scientific societies established new locations of knowing precisely by capitalizing on dislocation, whereas Streefland argues that the Netherlands could engineer its place in Cold War nuclear research by carefully managing an international network of contacts.

The long term perspective of this volume also allows for highlighting the transformations that locations underwent themselves. Their nature and the role co-evolved with knowledge practices, as is exemplified by the case of Teylers Museum, as discussed by Weiss in this volume. In a more general sense the emergence of modern universities is closely tied to concrete knowledge practices like disputations, lectures, and collecting, as well as the national interests of scientific research. The transformation of the city from the early modern period to the late twentieth century reminds us of the question raised by the mythic king Theseus: to what extent is the ship still the ship after all the parts have been gradually replaced over time. Likewise, the global networks of 
the Dutch continued to give shape to 'the Netherlands,' even when the nature of such networks changed from mercantile voyages to colonial governance to international collaboration. ${ }^{28}$ Whatever its parts, the Netherlands continues to navigate across the seven seas. The editors of this volume hope to have produced a useful compass to allow readers to take up the challenges presented in these chapters.

By conceptualizing locations of knowing as time-specific configurations of actors, artefacts and activities, the essays of this volume speak a clear language: over the last four hundred years, the Netherlands have witnessed the emergence of a variety of different locations at which scientific and other forms of knowledge were produced, disputed and often also rejected. Many of them are still visible until the present day. Taken together the essays in this volume show that understanding the histories of the Dutch Republic and the Kingdom of the Netherlands through its 'locations of knowing' offer historians a fruitful heuristics to bring different scales of analysis together: on one hand, our approach allows to study the complexities and often experimental character of knowledge production on a local scale. On the other hand, a locations perspective also serves as reminder that local dynamics of knowledge production cannot be analyzed disconnected from developments on a regional and global scale. Many of the locations we are discussing in this volume form part of wider geographies of communication, travel and exchange in which actors and artefacts not only from the Netherlands but also other parts of the world played an important role. By approaching the history of the Dutch Republic and the Kingdom of the Netherlands through some of its localities, we invite readers to work towards a spatialized understanding of knowledge production in the Netherlands in which local dynamics as well as regional and global entanglements remain never far out of sight.

28 The problem of 'transformation' is touched upon in the introduction to Transformations of Knowledge in Dutch Expansion, eds. Susanne Friedrich, Arndt Brendecke and Stefan Ehrenpreis (Berlin: De Gruyter, 2015). 